\title{
Evaluation of Decellularized Matrix and $\beta$-Tricalcium Phosphate as Biomaterials for Bone Neoformation. In vivo Study
}

\author{
Evaluación de la Matriz Descelularizada y $\beta$-Fosfato Tricálcico \\ como Biomateriales para Neoformación Ósea. Estudio In vivo
}

\begin{abstract}
Abraham Muñoz-Ruíz'; Erika Silva-Benítez²; Eduardo Soto-Sainz²; Bernardino Cerda-Cristerna ${ }^{3}$; Mariné Ortiz-Magdaleno ${ }^{4}$; Amaury Pozos-Guillen ${ }^{4} \&$ Héctor Flores $^{4}$
\end{abstract}

MUÑOZ-RUÍZ, A.; SILVA-BENÍTEZ, E.; SOTO-SAINZ, E.; CERDA-CRISTERNA, B.; ORTIZ-MAGDALENO, M.; POZOSGUILLEN, A. \& FLORES, H. Evaluation of decellularized matrix and $\beta$-tricalcium phosphate as biomaterials for bone neoformation. in vivo study. Int. J. Morphol., 35(3):804-811, 2017.

SUMMARY: The aim of this study was to evaluate histologically the effect of two biomaterials, a biomaterial derived from porcine Urinary submucosa Bladder Matrix (UBM) and beta-TriCalcium Phosphate ( $\beta$-TCP), on bone defects. Twenty male New Zealand rabbits were used; the models were divided in two groups: the UBM group; the $\beta$-TCP group, and a Negative Control (NC) group. Five$\mathrm{mm}$ defects were created in the femur of each model and then the different biomaterials were set in place depending on each group. At 4 and 8 weeks, the animals in the models were sacrificed and samples of the defect site were collected to perform a Hematoxylin and Eosin stain (H\&E). Histologically, $\beta$-TCP group at 4 and 8 weeks presented neoformation of bone-like and cartilage-like tissue, with the presence of inflammatory infiltrate; at 4 and 8 weeks, the UBM group presented neoformation of bone-like and cartilage-like tissue with a low presence of inflammatory infiltrate, and the NC group presented the formation of connective tissue and, in a low proportion, neoformation of bone tissue and cartilage. Both biomaterials, UBM and $\beta$-TCP, exhibited the capacity to promote bone neoformation; however, the UBM-based biomaterial produced a better-organized tissue with a lower inflammatory response compared with the $\beta$-TCP group.

KEY WORDS: Urinary bladder matrix; Bone regeneration; Biomaterial; $\beta$-tricalcium phosphate.

\section{INTRODUCTION}

Bone is a dynamic, highly vascularized tissue possessing a unique capacity of healing when under suitable biological conditions (Reichert et al., 2009). Currently, standard treatments to improve the regeneration process of bone tissue involves the use of bone grafts (Komaki et al., 2006; Reichert et al.; Walsh et al., 2008); however, this approach has some disadvantages; for example, in the case of autologous bone grafts, more time and a higher dose of anesthesia are needed, sometimes there is an insufficient graft, and the access to the donor site could be restricted. In addition, the surrounding tissues could be damaged, there is the possibility of producing cosmetic disability at the donor site, and risk of infection increases significantly (Komaki et $a l$; Reichert $e t a l$.). Other types of grafts employed include allografts and xenografts, but use of these involves the risk of immune rejection, sequestration of the graft, or even the risk of transmission of infections (Reichert et al.).
Tissue Engineering (TE) is a multidisciplinary field that applies principles of biology and engineering to the development of tissue substitutes to recover, maintain, or increase the function of diseased, damaged, or lost tissues (Silva-Benítez et al., 2015). The field of TE is focused on the need to provide functional equivalents of native tissues (Burdick \& Vunjak-Novakovic, 2009) and to avoid the limitations related with the standard treatments by creating an in vivo local environment, enabling cells to promote their proliferation and differentiation through the utilization of biomaterials (Tabata, 2009).

Biomaterials play a key role in creating the environment for cells (Tabata) and must have structural and functional properties (Badylak, 2002) to provide a framework and initial support for the cells in order for them to attach, proliferate, differentiate, and form an Extra Cellular

\footnotetext{
${ }^{1}$ Doctorado Institutional en Ingeniería y Ciencia de Materiales, Universidad Autónoma de San Luis Potosí, S.L.P., México.

${ }^{2}$ Facultad de Odontología, Universidad Autónoma de Sinaloa, Culiacán, Sin., México.

${ }^{3}$ Facultad de Odontología, Universidad Veracruzana (Rio Blanco), Orizaba, Ver., México.

${ }^{4}$ Laboratorio de Ciencias Básicas, Facultad de Estomatología, Universidad Autónoma de San Luis Potosí, San Luis Potosí, S.L.P., México.
} 
Matrix (ECM). Basically, biomaterials act as a synthetic ECM to organize cells into three-dimensional (3-D) architecture to provide the growth and formation of a new tissue (Drury \& Mooney, 2003).

In a living organism, cells are surrounded by other cells and are embedded in an ECM that defines the architecture, signaling, and biomechanics of the cellular microenvironment (Burdick \& Vunjak-Novakovic), rendering the ECM and its components an ideal biomaterial for TE. There are characteristics that make the ECM suitable for tissue regeneration as follows: it possesses structural and functional proteins that constitute part of the native mammalian ECM; it acts as a controlled-release vehicle of growth factors; it is a rich source of many types of collagen; it participate in the retention of growth factors from the surrounding tissues; it exerts an influence on the modulation of the immune host response; it guides the microenvironmental signals, and it has suitable biomechanical characteristics (Badylak, 2002; Badylak, 2007; Badylak et al., 2009; Liu et al., 2012; Benders et al., 2013). However, when the ECM is used as a biomaterial, there is the possibility of immune rejection (Badylak \& Gilbert, 2008, Badylak et al.) and a potential inflammatory response from the host (Badylak et al.; Silva-Benítez et al., 2015) related with the antigenic epitopes of the native cellules of the source tissue (Badylak \& Gilbert; Badylak et al.); nonetheless, the decellularization process of the ECM (Badylak et al.; Silva-Benítez et al., 2015) could be employed to avoid this limitation (Badylak \& Gilber; Badylak et al.; Silva-Benítez et al., 2015).

The porcine submucosa Urinary Bladder Matrix (UBM) is one of the most commonly ECM used as a biomaterial (Benders et al.; Silva-Benítez et al., 2015). It has demonstrated excellent biological properties compared with the ECM obtained from other tissues (Silva-Benítez et al., 2015) due to its composition and structure, in that the UBM mainly comprises collagen (90\%), principally types I, III, IV, V, VI, and VII (Badylak et al.), forming fibers with interconnections between them that allow for cell invasion and angiogenesis (Benders et al.), which permit the arrival of nutrients, cells, molecules, and growth factors (Zhou et al., 2010).

On the other hand, the $\beta$-TCP is a calcium phosphate porous ceramic with adequate biocompatibility and biodegradability (Komaki et al.), that possesses osteoconductive properties, and that has been proven to be effective in bone surgery (Walsh $e t a l$.).

Considering the limitations with the currently employed standard biomaterials, it is necessary to develop and evaluate novel biomaterials that contribute to rapid and well-organized tissue regeneration. The aim of this study was to evaluate histologically the regenerative effect of two biomaterials: $\beta$-TCP and an UBM-derived biomaterial on femur bone defects in rabbits.

\section{MATERIAL AND METHOD}

Animals. Twenty male New Zealand white rabbits (weighing $2.5-3.0 \mathrm{~kg}$ each) were used in this study. The models were divided into two experimental groups: lyophilized UBM; beta-TriCalcium Phosphate ( $\beta$-TCP) (Sigma-Aldrich, St Louis, MO, USA), and a Negative Control (NC) group. Lyophilized UBM was developed as previously mentioned in the literature (Silva-Benítez et al., 2014; Silva-Benítez et al., 2015). The study was approved by the Institutional Research Ethic Committee (CEI-FE-006-014). All procedures were performed following the International Guidelines Principles for Biomedical Research Involving Animals (CIOMS \& ICLAS, 2012) and the Occupational Health and Safety in the Care and Use of Research Animals Guide (National Research Council, 1997).

Surgical procedure. The surgical procedure was performed as previously described (Fialkov et al, 2003; Muise-Helmericks et al., 2011; Zhang et al., 2012; Patrascu et al., 2013). Briefly, each model was anesthetized with Ketamine $(40 \mathrm{mg} / \mathrm{kg})$ (Ketaset, USA) in combination with Xylazine $(5 \mathrm{mg} / \mathrm{kg}$ ) (Rompun, Bayer), and prior to each procedure, the surgery site was shaved and disinfected with a Povidone-Iodine (PI) solution. For surgical access, an incision with a no.- 15 blade was performed above the skin; then, the muscular fascia and muscle tissue were dissected to reach the anterolateral face of the femur to perform a 5$\mathrm{mm}$ defect in the bone (the measurement of the defect size was carried out with a millimetric ruler) with an electric motor and a number 702 surgical carbide bur under copious irrigation with saline solution (Figs. 1A and 1B). After the bone defect was created, the biomaterials were inserted into the defect according to each group until the bone defect was completely filled; subsequently, an X-Ray was performed (Figs. 2A \& 2B). In the NC group, no material was inserted. Finally, the surgical site was washed with saline solution and was sutured; for deep tissues, Vicryl suture 1-0 (Ethicon, USA) was utilized, while for the skin, silk suture 3-0 (Ethicon, USA) was employed. After the surgical procedure, each model was maintained in a comfortable place and transferred to a recovery room. Enrofloxacin $(10 \mathrm{mg} / \mathrm{kg} / 12 \mathrm{~h}$ ) was administered (Baytril, Bayer) as antibiotic and Ibuprofen ( $2 \mathrm{mg} / \mathrm{kg} / 12 \mathrm{~h}$ ) (Dalsy) as analgesic. 
Sacrifice of the model. The sacrifice of the animal models was performed by means of an intracardiac (i.c.) injection of Ketamine (Ketaset, USA) at 4 and 8 weeks after the surgical procedure.

Sample recovery. Samples (femur) of each model were collected and placed into $10 \%$ neutral formalin at $-4{ }^{\circ} \mathrm{C}$ until histological evaluation was performed.

Histological evaluation. Demineralization of each sample was conducted for 4 weeks using citric acid $(10 \%)$. Then sections
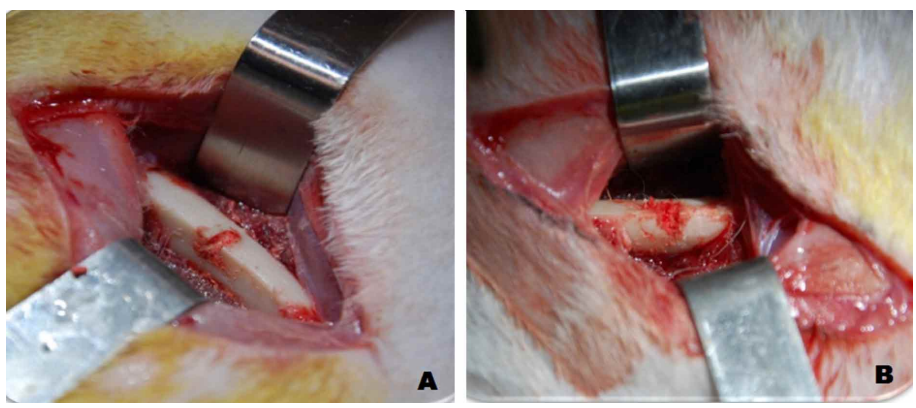

Fig. 1A. Femur bone defect $(5-\mathrm{mm})$ filled with $\beta$-TCP. B. Femur bone defect (5-mm) filled with lyophilized UBM.
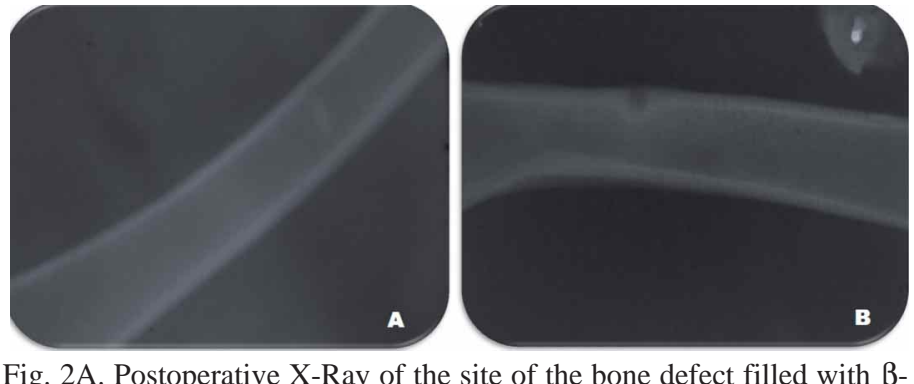

Fig. 2A. Postoperative X-Ray of the site of the bone defect filled with $\beta$ TCP. B. Postoperative X-Ray of the site of the bone defect filled with UBM. of each sample were obtained from the defect site and were placed under running water for $2 \mathrm{~h}$ to remove any remaining acid. The samples were processed in a Histokinette Leica TP-1020 with different grades of alcohol, acetone, and xylol. Shortly thereafter, paraffin blocks of each sample were obtained utilizing a Leica EG1150 H/C mounted in a Leica RM-2265 Microtome to perform 5-mm histological sections. Finally, the samples were stained with Hematoxylin and Eosin (H\&E) (MERCK).

\section{RESULTS}

Two blinded evaluators conducted a qualitative analysis of the histological characteristics of each group with an optic microscope at 10X and 40X. The histological characteristics evaluated included the presence and absence of angiogenesis, connective tissue, neoformation of cartilage-like tissue, and neoformation of bone-like tissue, as well as the intensity and type of inflammatory infiltrate.

When comparing the histological characteristics of the $\beta$-TCP, UBM, and NC groups at 4 and 8 weeks, the organization and quality of the tissue was best in the UBM group, followed by the $\beta$-TCP group and finally, the NC group. In the UBM group, organized tissue was observed with an increased number of cells and angiogenesis, and
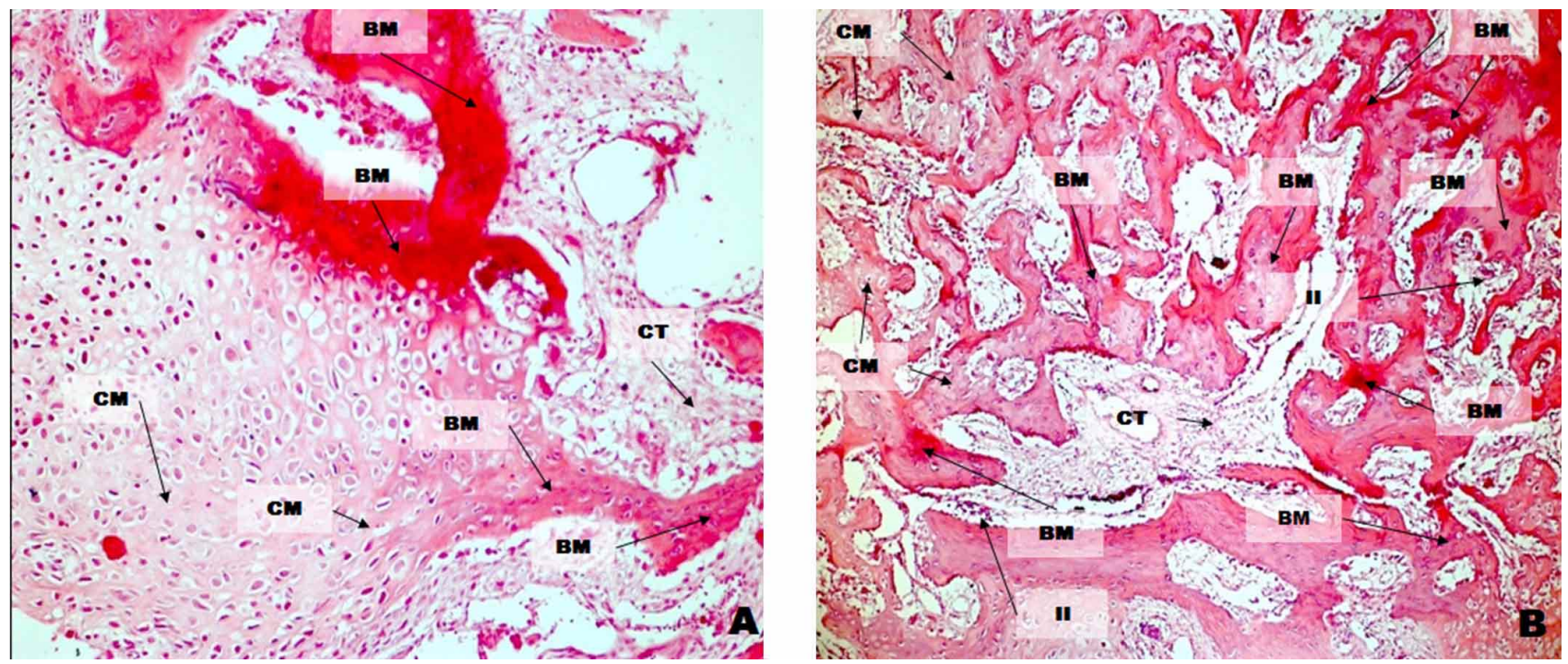

Fig. 3. Histological images of the UBM group at 4 weeks. A (10X); B (40X). Neoformation of cartilage-like and bone-like tissue; the neoformed tissue is in early stages of mineralization, and there is the presence of angiogenesis and the presence of a mild inflammatory infiltrate. $\mathrm{CT}=$ Connective Tissue. $\mathrm{CM}=$ Like-Cartilage Matrix. BM=Like-Bone Matrix. II=Inflammatory Infiltrate. 
deposits of cartilage-like and bone-like tissue also exhibited areas of mineralization (Figs. 3A, 3B, 4A, \& 4B); in the $\beta$ TCP group, less organized tissue was demonstrated with the presence of zones of matrix deposition in early mineralization stages and the presence of angiogenesis and cells (Figs. 5A, 5B, 6A, \& 6B); in the NC group, a less organized matrix is observed in comparison with the that of the two previous groups, and there was deposition of connective healing tissue, reduced angiogenesis, and a few mineralization sites (Figs. 7A - D).
When the inflammatory infiltrate was evaluated at 4 and 8 weeks, the $\beta$-TCP group at 4 weeks showed a low grade of inflammatory-process grade (Figs. 5A \& 5B), while at 8 weeks, the group exhibited an increase of this with a predominantly moderate chronic inflammatory process (Figs. 6A \& 6B). The UBM group at 4 weeks demonstrated a mild inflammatory process (Figs. 3A \& 3B), and at 8 weeks exhibited a reduction of the inflammatory process (Fig. 4A $\& 4 \mathrm{~B})$. The NC group at 4 and 8 weeks showed a mild-low inflammatory process (Figs. 7A - D).
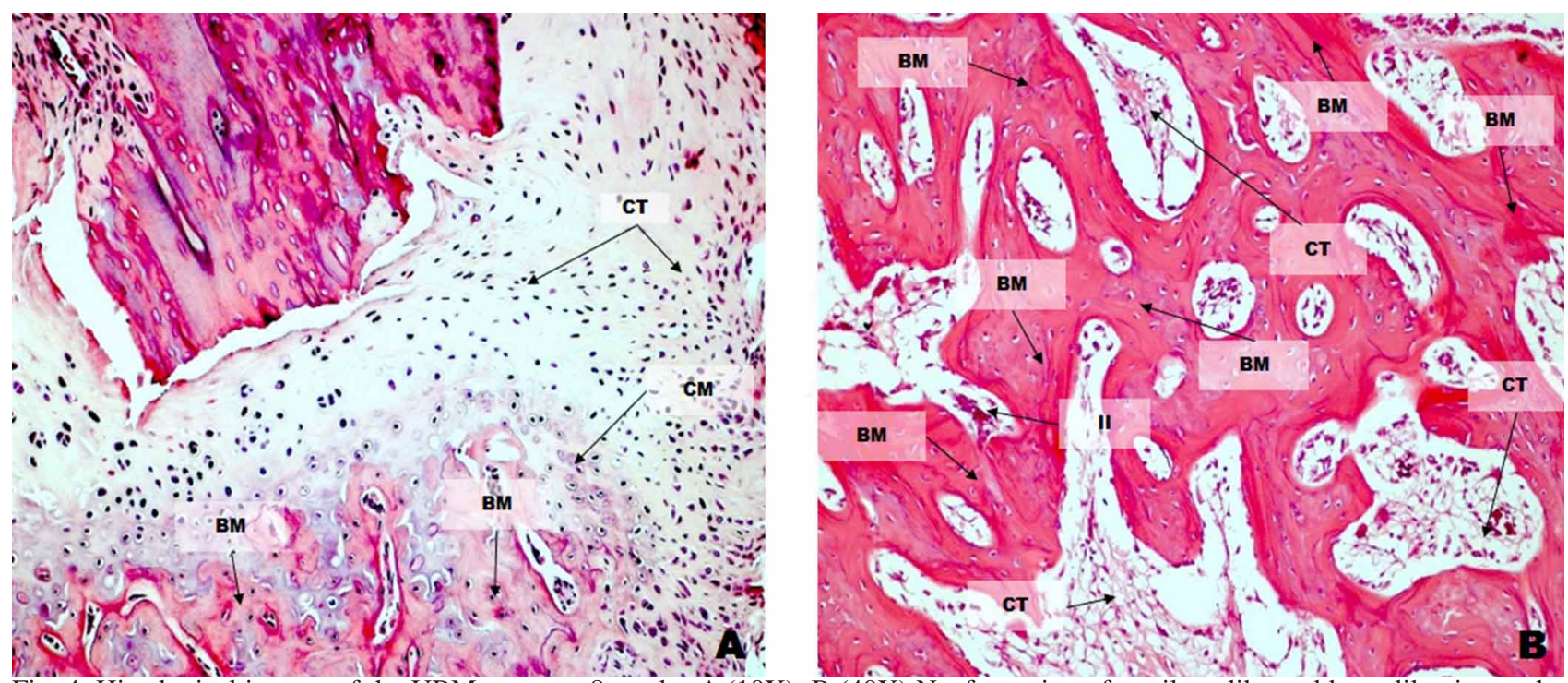

Fig. 4. Histological images of the UBM group at 8 weeks. A (10X): B (40X) Neoformation of cartilage-like and bone-like tissue; the neoformed tissue is in advanced stages of mineralization, and there is the presence of angiogenesis and a low presence of inflammatory infiltrate. CT=Connective Tissue. CM=Like-Cartilage Matrix. BM=Like-Bone Matrix. II=Inflammatory Infiltrate.
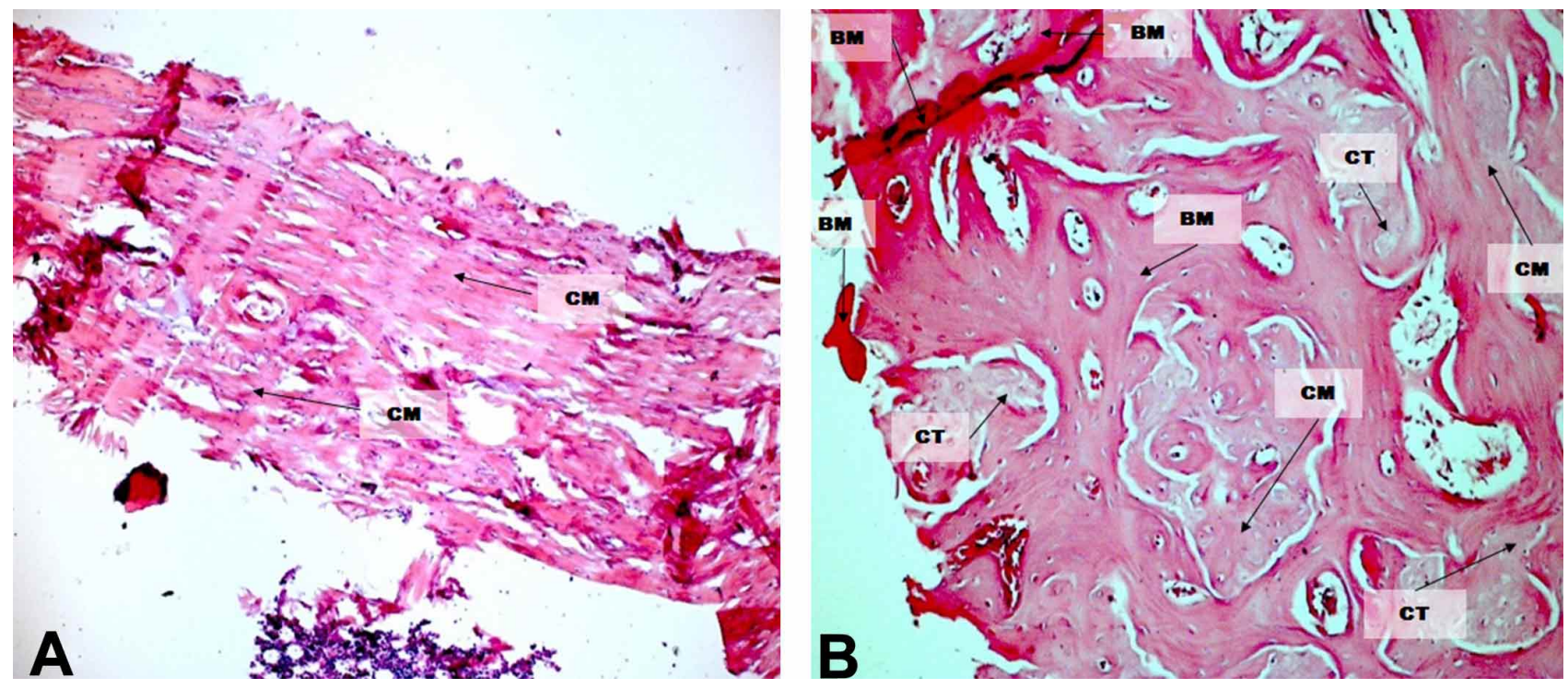

Fig. 5. Histological images of the $\beta$-TCP group at 4 weeks. A (10X); B (40X) Neoformation of cartilage-like and bone-like tissue; the neoformed tissue is in early stages of mineralization, and there is the presence of angiogenesis and the presence of a low grade of inflammatory infiltrate. $\mathrm{CT}=$ Connective Tissue. $\mathrm{CM}=$ Like-Cartilage Matrix. $\mathrm{BM}=$ Like-Bone Matrix. II=Inflammatory Infiltrate . 

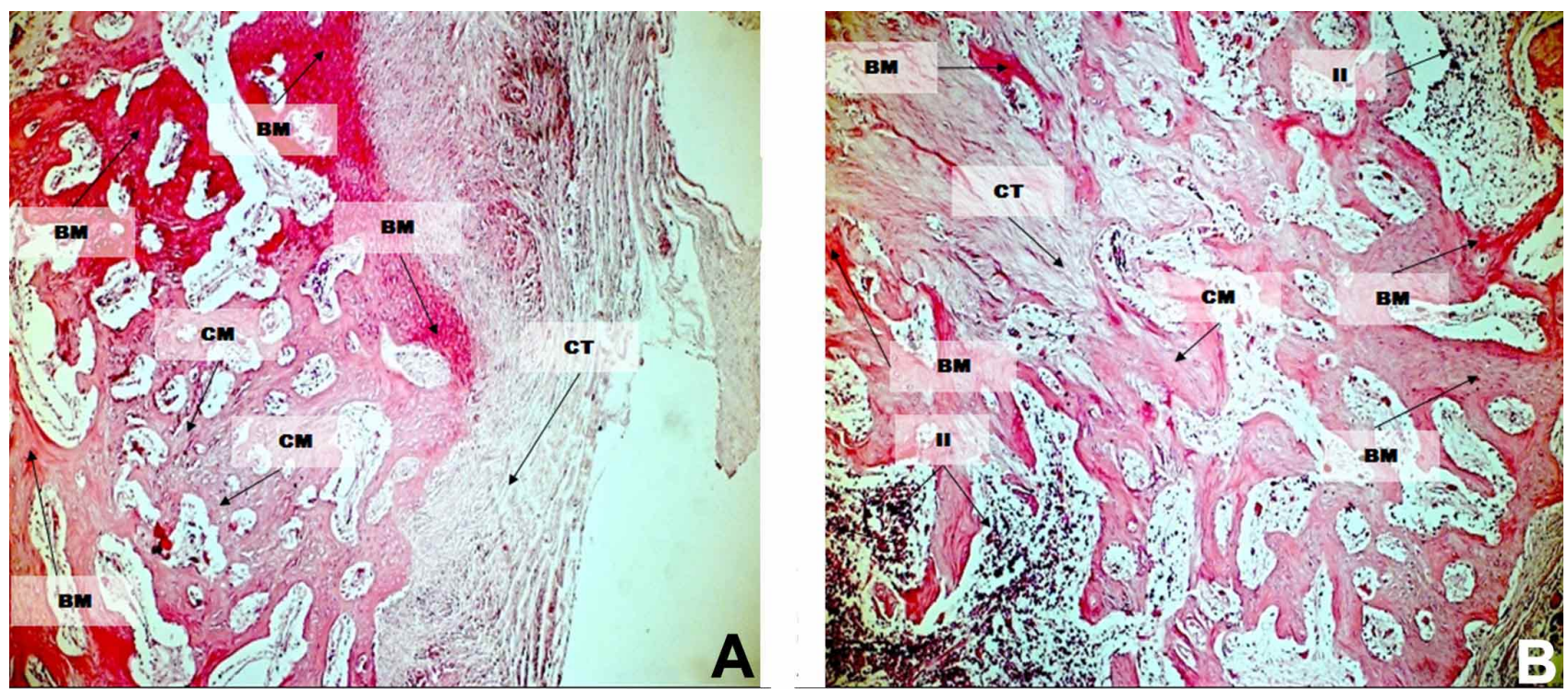

Fig. 6. Histological images of the $\beta$-TCP group at 8 weeks. A (10X); B (40X) Neoformation of cartilage-like and bone-like tissue; there is the presence of angiogenesis and a moderate chronic inflammatory process. $\mathrm{CT}=\mathrm{Connective} \mathrm{Tissue.} \mathrm{CM=Like-Cartilage} \mathrm{Matrix}$. BM=Like-Bone Matrix. II=Inflammatory Infiltrate.
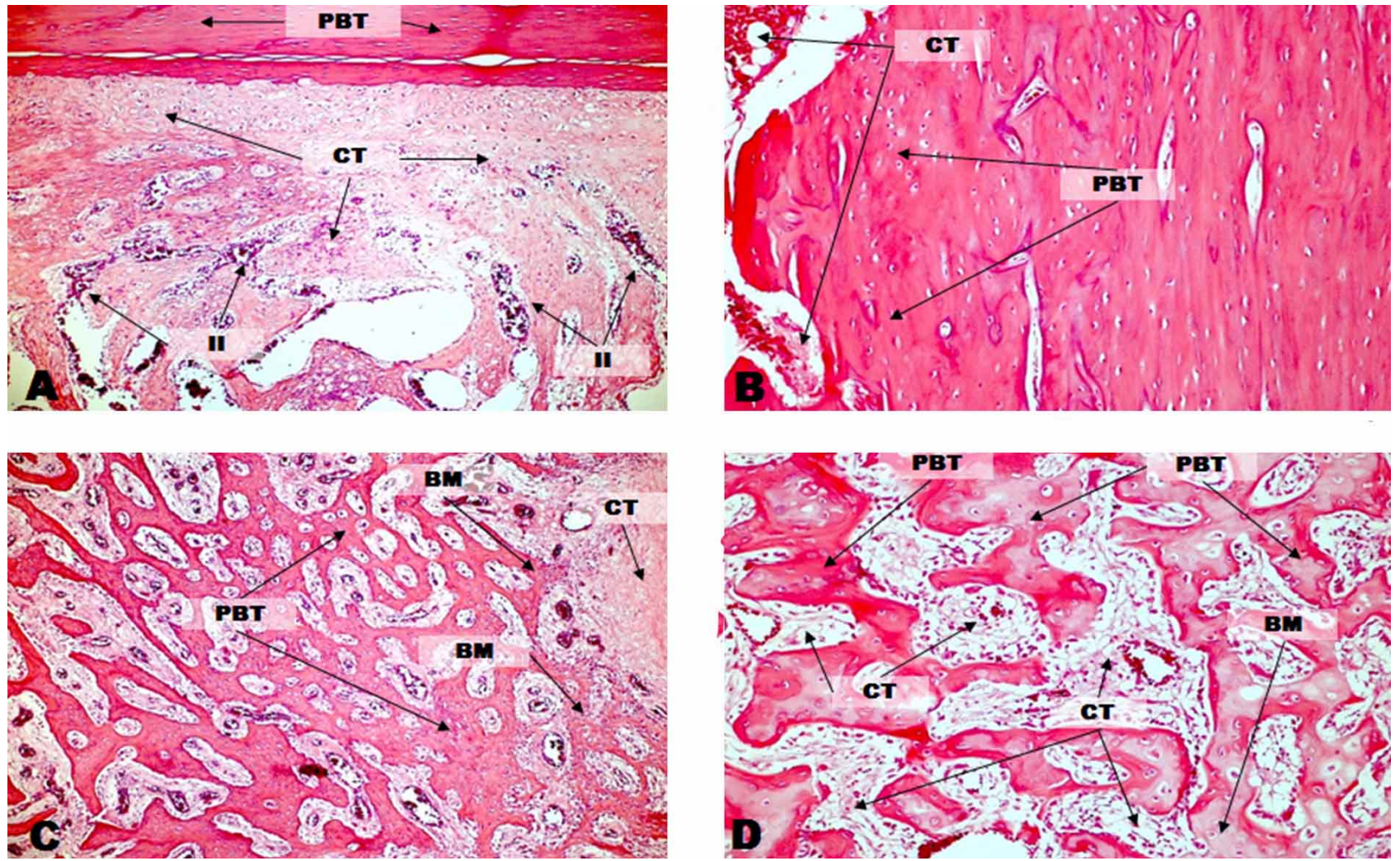

Fig. 7. Histological images of the Negative Control (NC) group. A(10X); B (10X) 4 weeks. Deposition of connective healing tissue with no presence of mineralization sites. C (10X); D (40X) 8 weeks. Neoformation of cartilage-like and bone-like tissue in a low proportion associated with the periphery of preexisting bone tissue with deposition of connective healing tissue and a low presence of mineralization sites in the center of the bone defect. PBT=Pre-existing Bone Tissue. CT=Connective Tissue. CM=Like-Cartilage Matrix. BM=LikeBone Matrix. II=Inflammatory Infiltrate. 


\section{DISCUSSION}

In the present study, the use of two biomaterials for bone regeneration was reported: one biomaterial based on UBM, and the other on $\beta$-TCP. The results obtained indicate that both materials induce the neoformation of bone-like tissue, corroborating data reported in other studies; Ramalingam et al. (2016) evaluated histologically and by micro-Computed Tomography (micro-CT), the use of $\beta$-TCP alone, and the use of $\beta$-TCP in combination with a collagen membrane in calvarial defects in rats after 10 weeks of implantation. The results indicated that $\beta$-TCP alone induced neoformation of bone with the presence of fibrous connective tissue, but with remnants of the biomaterial and inflammatory cells in some areas. In the $\beta$-TCP-collagen group, there was the presence of neoformation of bone with the presence of osteocytes, connective tissue, neovascularization, and the presence of remnants of the biomaterial with inflammatory infiltrate. The authors concluded that the newly formed bone was enhanced by the collagen employed; in comparison with the present study, the results are similar in relation with the neoformed bone-like tissue and with the presence of inflammatory infiltrate in the $\beta$-TCP group. On the other hand, when the UBM-based biomaterial was utilized, the neoformed tissues histologically demonstrated a more organized and mature structure in comparison with that of the $\beta$-TCP group.

Walsh et al. (2008) evaluated three commercially bTCP-based materials in bilateral tibial metaphyseal defects in New Zealand white rabbits and the authors appraised three materials. Histological evaluation at 4 weeks postimplantation demonstrated new bone growth and, at 12 weeks postimplantation, there was resorption of the material. Additionally, the samples showed no evidence of adverse foreign-body response. These data differ from those of our results in which there was the presence of inflammatory infiltrate in the $\beta$-TCP group. These results could be due to that the $\beta$-TCP tested was not a material specifically designed for implantation and that perhaps the properties of the $\beta$ TCP tested were not ideal for this purpose. Another consideration is the size of the defect; in the present study, an important mechanical stress was present due to the defect type and the defect site, which modified the behavior of the biomaterial and the response from the host, influencing the reabsorption velocity of the biomaterial.

Lee et al. (2010) reported the ability of porcinederived collagen nanofibrous membrane to enhance bone regeneration in one-wall intra-bony periodontal defects in beagle dogs after 10 weeks of implantation. The authors concluded that collagen membrane enhanced bone regeneration in one-wall intra-bony defects, but with no influence on periodontal tissue regeneration; these results support the data obtained in the present study in which we utilized a UBM-based biomaterial with a collagen-rich composition that promotes the neoformation of bone-like tissue by the formation of an adequate microenvironment for cell proliferation, organization, and the formation of a new matrix.

Our results could be due to the factors related with the specific characteristics and properties of each of biomaterial. It is know that biomaterials with porous or interconnections allow good interaction with host cells and tissues, with the invasion of proteins and cells required for bone formation and resorption. At the same time, it is known that dense materials without pores exhibit little degradation, preventing suitable matrix deposition and mineralization, a structure with interconnections or porous (Komaki et al.). In the case of $\beta$-TCP, these present porous that permit the infiltration of osteogenic cells and angiogenesis: in addition, the porosity of the $\beta$-TCP is crucial to its rapid degradation, facilitating contact with host cells and resulting increased contact of osteoclastic cells with the material; the ability of these cells to penetrate and reabsorb the $\beta$-TCP contributes to the replacement of the biomaterial for bone tissue (Yoneda et al., 2005).

In case of ECM-based biomaterials, these possess components such as structural and functional molecules that are secreted by the living cells of the tissue- or organ-ofsource (Badylak et al.) and are able to retain growth factors that are produced naturally in the adjacent tissues in response to the implantation (Benders et al.). Also, ECM-based biomaterials usually present interconnections among collagen fibers that permit cell invasion and angiogenesis (Benders et al.). This increased angiogenesis in turn allows for the arrival of nutrients, cells, molecules, and growth factors at the site, which determines the effectiveness of healing and bone formation (Zhou et al.). ECM-based biomaterials should be considered as controlled-release vehicles of growth factors and a rich source of many types of collagen (Badylak, 2002). These and the abundant cell infiltrate, mitogenesis, and deposition of new ECM residents comprise the most relevant events when biomaterials are employed (Badylak, 2007).

The inflammatory process is an essential step in tissue repair and regeneration, because the inflammation permits the elimination of harmful agents, allowing the recruitment of cells and functional molecules to the site-of-injury; nonetheless, if this process is perpetuated, it becomes chronic and pathological, interfering with healing and tissue regeneration (Kumar et al., 2004). In this study, we evaluated 
the inflammatory infiltrate at 4 and 8 weeks in each group, and the $\beta$-TCP group produced a more intense inflammatory response than the UBM and the NC groups. This may be due to that $\beta$-TCP was able to be recognized as a foreign body by the immune system, initiating an inflammatory response with the intention of removing the agent. Unlike the UBM group, the inflammatory infiltrate was lower, this perhaps due to that because the composition of the source matrix is mainly collagen types I and III and, in a lesser proportion collagen type VII (Badylak et al.); the latter collagen possesses excellent biocompatibility and the ability to contribute to the repair/healing process. Collagen-based biomaterials additionally revealed no adverse effects on surrounding tissues during the degradation process, this being another advantage of biomaterials over synthetic materials, which commonly induce foreign-body reactions during degradation (Lee et al.). These ECM-based biomaterials are superior to other materials because they have optimal characteristics, including structural and functional proteins that are part of the native ECM of mammals, a unique 3-D organization (Liu et al.), which contains bioactive molecules (Benders et al.), that can be remodeled, reabsorbed, and that can give rise to tissue regeneration rather than scar tissue (Liu et al.).

Despite the adequate characteristics and properties of the ECM as biomaterial, the use of an ECM of xenogeneic origin involves an increased risk of immune rejection by the host, manifesting an inflammatory process. To avoid this, it is possible to treat the ECM by decellularization (SilvaBenítez et al., 2014; Silva-Benítez et al., 2015), which renders it possible to remove the majority of the antigenic epitopes. The presence of the Gal epitope on the surface of the vascular endothelium is the first cause for rejection of xenogeneic transplants (Badylak \& Gilber). However, when these biomaterials or implants are treated with a decellularization process, it has been demonstrated that ECM-based biomaterials induce $T$ cells to differentiate into Th2 cells, this eventually resulting in acceptance of the implant (Liu et al.). Further studies are needed in order to identify specific markers associated with osteoblastic lineage.

In conclusion, the biomaterials evaluated in this study produced neoformation of bone-like tissue; however, the biomaterial based on lyophilized decellularized matrix from porcine urinary bladder produced a better and more organized tissue, and also produced a reduced inflammatory response compared with the use of $\beta$-TCP.

ACKNOWLEDGMENTS. This work was partly supported by the "Programa de Fortalecimiento de la UASLP/PIFI 2013"; the authors thank Dr. Eri Peña, from the Pediatric
Hospital of Culiacan, Sinaloa, México, for the support with the histological process and histological evaluation; and Dra. Sarai Romo, from the Universidad Autónoma de San Luis Potosí, SLP, México, for the support with the histological evaluation. The reviewing of the manuscript by Maggie Brunner has been particularly appreciated.

MUÑOZ-RUÍZ, A.; SILVA-BENÍTEZ, E.; SOTO-SAINZ, E.; CERDA-CRISTERNA, B.; ORTIZ-MAGDALENO, M.; POZOS-GUILLEN, A. \& FLORES, H. Evaluación de la matriz descelularizada y b-fosfato tricálcico como biomateriales para neoformación ósea. Estudio in vivo. Int. J. Morphol., 35(3):804811, 2017.

RESUMEN: El objetivo de este estudio fue evaluar histológicamente el efecto de dos biomateriales: derivado de matriz de submucosa de vejiga urinaria porcina (UBM) y b-fosfato tricálcico ( $\beta$-TCP) en defectos óseos. Veinte conejos macho de raza Nueva Zelanda fueron empleados para este estudio; los modelos fueron divididos en dos grupos: UBM, $\beta$-TCP y un grupo control negativo. Se crearon defectos de $5 \mathrm{~mm}$ en el fémur de cada uno de los modelos y posteriormente se colocó el biomaterial correspondiente de acuerdo a cada uno de los grupos. A las 4 y 8 semanas los modelos fueron sacrificados y se tomaron muestras del sitio del defecto óseo para realizar una tinción de Hematoxilina y Eosina. Histológicamente el grupo de $\beta$-TCP tanto a las 4 como a las 8 semanas mostró neoformación de tejido óseo y tejido cartilaginoso con presencia de infiltrado inflamatorio; el grupo de UBM a las 4 y 8 semanas presentó neoformación de tejido óseo, tejido cartilaginoso y un bajo infiltrado inflamatorio; el grupo control negativo presentó formación de tejido conectivo y en baja proporción neoformación de tejido óseo y cartílago. Ambos biomateriales, UBM y $\beta$-TCP mostraron la capacidad de promover la neoformación de tejido óseo; sin embargo, el biomaterial basado en UBM produjo un tejido mejor organizado y un menor infiltrado inflamatorio en comparación con el $\beta$-TCP.

PALABRAS CLAVE: Matriz urinaria porcina; Regeneración ósea; Biomaterial; $\beta$-fosfato tricálcico.

\section{REFERENCES}

Badylak, S. F. \& Gilbert, T. W. Immune response to biologic scaffold materials. Semin. Immunol., 20(2):109-16, 2008.

Badylak, S. F. The extracellular matrix as a biologic scaffold material. Biomaterials, 28(25):3587-93, 2007.

Badylak, S. F. The extracellular matrix as a scaffold for tissue reconstruction. Semin. Cell Dev. Biol., 13(5):377-83, 2002.

Badylak, S. F.; Freytes, D. O. \& Gilbert, T. W. Extracellular matrix as a biological scaffold material: Structure and function. Acta Biomater, 5(1):1-13, 2009.

Benders, K. E. M.; van Weeren, P. R.; Badylak, S. F.; Saris, D. B.; Dhert, W. J. \& Malda, J. Extracellular matrix scaffolds for cartilage and bone regeneration. Trends Biotechnol., 31(3):169-76, 2013.

Burdick, J. A. \& Vunjak-Novakovic, G. Engineered microenvironments for controlled stem cell differentiation. Tissue Eng. Part A, 15(2):205- 
19, 2009.

Council for International Organization of Medical Sciences \& the International Council for Laboratory Animal Science (CIOMS \& ICLAS). International Guiding Principles for Biomedical Research Involving Animals, 2012. Available from: https:/grants.nih.gov/grants/ olaw/guiding_principles_2012.pdf

Drury, J. L. \& Mooney, D. J. Hydrogels for tissue engineering: scaffold design variables and applications. Biomaterials, 24(24):4337-51, 2003.

Fialkov, J. A.; Holy, C. E.; Shoichet, M. S. \& Davies, J. E. In vivo bone engineering in a rabbit femur. J. Craniofac. Surg., 14(3):324-32, 2003.

Komaki, H.; Tanaka, T.; Chazono, M. \& Kikuchi, T. Repair of segmental bone defects in rabbit tibiae using a complex of beta-tricalcium phosphate, type I collagen, and fibroblast growth factor-2. Biomaterials, 27(29):5118-26, 2006.

Kumar, V.; Cotran, R. S. \& Robbins, S. L. Patología Humana. $7^{\text {th }}$ ed. Madrid, Elsevier, 2004.

Lee, C. K.; Koo, K. T.; Kim, T. I.; Seol, Y. J.; Lee, Y. M.; Rhyu, I. C.; Ku, Y.; Chung, C. P.; Park, Y. J. \& Lee, J. Y. Biological effects of a porcinederived collagen membrane on intrabony defects. J. Periodontal. Implant Sci., 40(5):232-8, 2010

Liu, L.; Deng, L.; Wang, Y.; Ge, L.; Chen, Y. \& Liang, Z. Porcine urinary bladder matrix-polypropylene mesh: a novel scaffold material reduces immunorejection in rat pelvic surgery. Int. Urogynecol. J., 23(9):1271$8,2012$.

Muise-Helmericks, R. C.; Demcheva, M.; Vournakis, J. N. \& Seth, A. Poly$\mathrm{N}$-acetyl glucosamine fibers activate bone regeneration in a rabbit femur injury model. J. Trauma, 71(2 Suppl. 1):S194-6, 2011.

National Research Council. Occupational Health and Safety in the Care and Use of Research Animals. Washington D. C., The National Academies Press, 1997.

Patrascu, J. M.; Krüger, J. P.; Böss, H. G.; Ketzmar, A. K.; Freymann, U.; Sittinger, M.; Notter, M.; Endres, M. \& Kaps, C. Polyglycolic acidhyaluronan scaffolds loaded with bone marrow-derived mesenchymal stem cells show chondrogenic differentiation in vitro and cartilage repair in the rabbit model. J. Biomed. Mater. Res. B Appl. Biomater, 101(7):1310-20, 2013.

Ramalingam, S.; Al-Rasheed, A.; ArRejaie, A.; Nooh, N.; Al-Kindi, M. \& Al-Hezaimi, K. Guided bone regeneration in standardized calvarial defects using beta-tricalcium phosphate and collagen membrane: a realtime in vivo micro-computed tomographic experiment in rats. Odontology, 104(2):199-210, 2016.

Reichert, J. C.; Saifzadeh, S.; Wullschleger, M. E.; Epari, D. R.; Schütz, M. A.; Duda, G. N.; Schell, H.; van Griensven, M.; Redl, H. \& Hutmacher, D. W. The challenge of establishing preclinical models for segmental bone defect research. Biomaterials, 30(12):2149-63, 2009.

Silva-Benítez, E. L.; Soto-Sainz, J. E.; Gordillo-Moscoso, A.; MedellínCastillo, H. I.; Romero-Quintana, J. G.; Pozos-Guillen, A. J.; RamosPayán, R. \& Flores, H. Designing a biofunctionalized extracellular matrix for bone regeneration. Dent. Mater., 30 (Suppl. 1):e179, 2014.

Silva-Benítez, E.; Soto-Sainz, E.; Pozos-Guillen, A.; Romero-Quintana, J. G.; Aguilar-Medina, M.; Ayala-Ham, A.; Peña-Martínez, E.; RamosPayán, R. \& Flores, H. Quantification of DNA in urinary porcine bladder matrix using the ACTB gene. In Vitro Cell. Dev. Biol. Anim., 51(10):1040-6, 2015.

Tabata, Y. Biomaterial technology for tissue engineering applications. J. $R$. Soc. Interface, 6(Suppl. 3):S311-24, 2009.

Walsh, W. R.; Vizesi, F.; Michael, D.; Auld, J.; Langdown, A.; Oliver, R.; Yu Y.; Irie, H. \& Bruce, W. Beta-TCP bone graft substitutes in a bilateral rabbit tibial defect model. Biomaterials, 29(3):266-71, 2008.

Yoneda, M.; Terai, H.; Imai, Y.; Okada, T.; Nozaki, K.; Inoue, H.; Miyamoto, S. \& Takaoka, K. Repair of an intercalated long bone defect with a synthetic biodegradable bone-inducing implant. Biomaterials, 26(25):5145-52, 2005.

Zhang, W.; Wang, W.; Chen, Q. Y.; Lin, Z. Q.; Cheng, S. W.; Kou, D. Q.; Ying, X. Z.; Shen, Y.; Cheng, X. J.; Nie, P. F.; Li, X. C.; Rompis, F. A.; Huang, H.; Zhang, H.; Mu, Z. L. \& Peng, L. Effect of calcium citrate on bone integration in a rabbit femur defect model. Asian Pac. J. Trop. Med., 5(4):310-4, 2012.

Zhou, J.; Lin, H.; Fang, T.; Li, X.; Dai, W.; Uemura, T. \& Dong, J. The repair of large segmental bone defects in the rabbit with vascularized tissue engineered bone. Biomaterials, 31(6):1171-9, 2010.

\author{
Corresponding author: \\ Héctor Flores \\ Laboratorio de Ciencias Básicas \\ Facultad de Estomatología \\ Universidad Autónoma de San Luis Potosí \\ Av. Dr. Manuel Nava \# 2 \\ Zona Universitaria \\ C.P. 78290 \\ San Luis Potosi S.L.P. \\ MÉXICO
}

E-mail: heflores@uaslp.mx

Received: 07.03.2017

Accepted: 19-05-2017 